Vol. 5 (1996): 399-412.

\title{
Effects of physical treatment of barley and rapeseed meal in dairy cows given grass silage-based diets
}

\author{
Pekka Huhtanen and Terttu Heikkilä \\ Agricultural Research Centre of Finland, Institute of Animal Production, \\ FIN-31600 Jokioinen, Finland
}

\begin{abstract}
Twenty-four Ayrshire cows were used to study the effects of physical treatment of barley, rapeseed meal (RSM) supplementation and heat-moisture treatment of RSM on silage intake and milk production. Experimental design was a cyclic change-over with six dietary treatments. The treatments in a 2 x 3 factorial arrangement consisted of either untreated (UB) or heat-moisture treated barley (TB), given without protein supplementation (control) or with untreated or heat-moisture treated RSM. Grass silage was given ad libitum and the concentrates at a rate of $10 \mathrm{~kg} / \mathrm{d}$. For the RSM diets, $2 \mathrm{~kg} / \mathrm{d}$ of the basal concentrate was replaced with either untreated or treated RSM.

Treatment of barley decreased silage intake, the effect being greater when the supplement did not contain RSM. There was no effect on milk yield, but due to the lower milk fat content, energy corrected milk yield was lower in cows given TB than in those given UB. Feeding the TB diets was also associated with lower milk urea content, and with increased milk protein content but not protein yield. Faster initial rate of gas production in vitro suggested that the treatment of barley increased the rate of fermentation. Compared with the control diets, RSM supplementation significantly increased silage intake, milk yield, milk protein content and yields of all milk constituents. Heat-moisture treatment of RSM did not produce any further production response.
\end{abstract}

Key words: milk production, feed intake, protein supplementation, digestibility, heat treatment

\section{Introduction}

It is well established that increasing the protein concentration of supplements increases milk yield in cows given grass silage-based diets (Thomas and Rae 1988, Chamberlain et al. 1989, Tuori 1992). The responses can be attributed to increased silage DM intake, improved diet di- gestibility and increased supply of amino acids from the small intestine. However, physical and chemical treatments of protein supplements to increase the supply of amino acids from the small intestine have often produced limited responses in animal production. Replacing grain mixture in the concentrate with rapeseed meal (RSM), the most important protein supplement for ruminants in Finland, has consistently increased 


\section{AGRICULTURAL AND FOOD SCIENCE IN FINLAND}

\section{Huhtanen, P. \& Heikkilä, T. Treated barley and rapeseed meal for dairy cows}

milk yield. However, reducing ruminal protein degradability of 00 -varieties of RSM by heatmoisture treatment has not produced any further responses (Tuori 1992) despite an increase in the calculated supply of amino acids absorbed from the small intestine (AAT).

Reducing ruminal protein degradability of grain supplements by either chemical or physical processing offers another way to increase the supply of amino acids. Although cereal grains have a low crude protein content, they generally comprise a large proportion of concentrate mixtures, which means that improvements in the protein value of grain could result in considerable increases in the supply of amino acids from the small intestine. Kassem et al. (1987) demostrated some improvements in milk production when barley was treated with a formaldehyde reagent. Physical treatment of grain can be used to modify grain starch, which should increase microbial protein synthesis in the rumen (Chamberlain et al. 1993). Heat treatment can produce complexes between starch and protein that are not digested by microbial enzymes (Dreher et al. 1984) and if these complexes are digested in the small intestine, the supply of both amino acids and glucose could increase.

The objective of our experiment was to examine the effects of physical treatment to reduce ruminal protein degradability of barley and rapeseed meal (RSM) on milk production in cows fed grass silage ad libitum.

\section{Material and methods}

\section{Animals}

The experimental animals were 24 Finnish Ayrshire cows, of which 6 were in their first lactation. The cows had calved 63 days (SE 4.0) before the start of the experiment and their average milk yield was $34.0 \mathrm{~kg}$ (SE 0.86) at the beginning of the experiment. The cows were fed and housed in individual stalls. Grass silage was given ad libitum in amounts ensuring refusal of about $10 \%$ of the amount offered. The concentrate mixtures were given three times daily at $1.00,13.00$ and $16.30 \mathrm{~h}$ and the cows were milked twice daily at 6.45 and $15.30 \mathrm{~h}$.

\section{Experimental design}

The experiment was conducted according to a cyclic change-over design (Davis and Hall 1969) with six treatments, four replicate blocks of six cows and four 3-week experimental periods. The cows were divided into blocks according to pretrial milk yield and parity, and allocated at random to treatments and sequences of treatments. The six treatments in a $2 \times 3$ factorial arrangement consisted of two energy supplements [untreated barley (UB) and heat-moisture-treated barley (TB)], each given without protein supplement (control), with untreated RSM or with treated RSM. The control concentrate consisted on a DM basis $(\mathrm{g} / \mathrm{kg})$ of either UB or TB (800) and molassed sugar beet pulp (200). For the cows given RSM diets, $200 \mathrm{~g} / \mathrm{kg}$ of the basal concentrate was replaced with RSM. On air-dry basis $(870 \mathrm{~g} \mathrm{DM} / \mathrm{kg})$, the concentrates were given at a rate of $10 \mathrm{~kg} / \mathrm{d}$ throughout the experiment. The concentrate mixtures contained $36 \mathrm{~g} / \mathrm{kg}$ of a commercial mineral mixture containing $(\mathrm{g} / \mathrm{kg}) \mathrm{Ca}$ (213), P (46), Mg (33) and $\mathrm{Na}(93)$.

Four late-lactation cows, each fitted with a rumen cannula, were used in a change-over design with two periods of 14 days to study the effects of barley treatment on rumen fermentation. The cows were given grass silage ad libitum and $2 \mathrm{~kg} / \mathrm{d}$ of untreated RSM with $6 \mathrm{~kg} / \mathrm{d}$ of either UB or TB. They were fed twice daily at $12 \mathrm{~h}$ intervals. Rumen samples were taken on the last day of each period before feeding and thereafter 8 times at $1 \mathrm{~h}$ intervals.

\section{Feeds}

The silage was made from a sward of secondcut meadow fescue (Festuca pratensis) - timo- 
Vol. 5 (1996): 399-412.

thy (Phleum pratense). The silage was harvested as direct-cut by a flail-type forage harvester and ensiled into a bunker silo of 200 t capacity. Formic acid-based additive was applied at ensiling at a rate of $5 \mathrm{l} / \mathrm{t}$.

The ingredients of the basal concentrates were crushed and mixed in the feed mill of the institute. RSM was weighed separately and mixed with the concentrate before feeding. Untreated RSM was solvent extracted and of Finnish origin (Raisio Ltd). Heat-moisture treated RSM was imported from Sweden, because for practical reasons it was not possible to transport RSM to Sweden for the treatment. The higher crude protein content of treated (Expro ${ }^{\circledR}$ ) RSM was taken into account by making the concentrates isonitrogenous. The treated barley was prepared from the same lot of barley that was fed untreated, by cooking at high temperature.

\section{Experimental procedure}

Feed intake and milk yield of individual cows were recorded daily. The results of the last seven days of each period were used for statistical analyses, and the feed samples for chemical analyses were collected during this period. Fresh silage samples were preserved frozen at $-20^{\circ} \mathrm{C}$ for the analyses of silage fermentation characteristics.

Milk samples were taken on four consecutive milkings on the last week of each period. The samples were analysed for fat, protein and lactose by an infra-red milk analyser. Live weight of the cows was recorded on two consecutive days at the beginning of the experiment and at the end of each period. The apparent digestibility of the diets was determined by using acid insoluble ash as an internal marker (Van Keulen and Young 1977). Faecal samples were taken from all cows twice daily at 7.30 am and $4 \mathrm{pm}$ on five consecutive days during the last week of each period. Ruminal protein degradability of the concentrate feeds was determined by nylon bag technique. The samples were incubated in the rumen of four cows for $0,3,6,12,24$ and $48 \mathrm{~h}$.
Efficient ruminal protein degradability (EPD) was calculated using the values of 0.03 and $0.04 / \mathrm{h}$ for the passage rate of barley and RSM (Tuori et al. 1995). Cumulative gas production was measured from barley samples by a modification of the method of Theodorou et al. (1994).

\section{Chemical analyses}

Feed analyses were made using standard procedures. Silage DM content was corrected for the volatile losses according to Huida et al. (1986). Neutral detergent fibre (NDF), acid detergent fibre (ADF) and lignin were determined according to Robertson and Van Soest (1981). The pH of the silage and rumen fluid samples was measured immediately. Ammonia-N (McCullough 1967) and volatile fatty acids (VFA) (Huida 1973) were measured both in silage and in rumen fluid samples. The concentration of lactic acid in silage was determined by the method of Barker and Summerson (1941) and that of water soluble carbohydrates (WSC) by the method of Somogyi (1945). Milk fatty acid composition was analysed by gas chromatography (Antila and Kankare 1983, Karow et al. 1984) and milk urea content as ammonia (McCullough 1967) after hydrolyses by urease.

\section{Calculations and statistical analyses}

The content of metabolizable energy (ME) was calculated using the D-value determined in sheep for silage and from chemical composition and digestibility coefficients (Tuori et al. 1995) for the concentrate feeds. ME intake was also estimated from calculated intake of digestible OM (DOM) assuming ME content of $16 \mathrm{MJ} / \mathrm{kg} \mathrm{DOM}$. Milk energy content was calculated according to Tyrrel and Reid (1965). The efficiency of the utilization of ME for milk production was calculated ignoring the effect of live weight change. The supply of amino acids absorbed from the small intestine (AAT) was estimated either by using EPD values determined by nylon bag meth- 


\section{AGRICULTURAL AND FOOD SCIENCE IN FINLAND}

Huhtanen, P. \& Heikkilä, T. Treated barley and rapeseed meal for dairy cows

Table 1. Chemical composition ( $\mathrm{g} / \mathrm{kg}$ dry matter) and calculated feeding values of the experimental feeds.

\begin{tabular}{|c|c|c|c|c|c|}
\hline & Silage $^{\prime}$ & $\begin{array}{l}\text { Untreated } \\
\text { barley }^{2}\end{array}$ & $\begin{array}{l}\text { Treated } \\
\text { barley }^{2}\end{array}$ & $\begin{array}{l}\text { Untreated } \\
\text { RSM }\end{array}$ & $\begin{array}{c}\text { Treated } \\
\text { RSM }\end{array}$ \\
\hline $\begin{array}{l}\text { Dry matter }(\mathrm{g} / \mathrm{kg}) \\
\text { In dry matter }\end{array}$ & 241 & 882 & 912 & 883 & 895 \\
\hline Ash & 87 & 66 & 63 & 78 & 79 \\
\hline Crude protein & 133 & 126 & 122 & 366 & 409 \\
\hline Ether extract & 50 & 17 & 19 & 39 & 32 \\
\hline Crude fibre & 283 & 73 & 73 & 137 & 120 \\
\hline $\mathrm{NFE}^{3}$ & 447 & 719 & 723 & 381 & 360 \\
\hline NDF & 522 & 275 & 379 & 292 & 283 \\
\hline $\mathrm{ADF}$ & 294 & 86 & 101 & 218 & 176 \\
\hline Lignin & 29 & 17 & 23 & 78 & 66 \\
\hline $\mathrm{EPD}^{4}(\mathrm{~g} / \mathrm{kg})$ & & 801 & 726 & 751 & 581 \\
\hline $\mathrm{ME}^{5}(\mathrm{MJ} / \mathrm{kg} \mathrm{DM})$ & 10.9 & 12.8 & 12.9 & 11.2 & 11.2 \\
\hline $\mathrm{AAT}^{6}(\mathrm{~g} / \mathrm{kg} \mathrm{DM})$ & 82 & 105 & 110 & 134 & 181 \\
\hline $\mathrm{PBV}^{7}(\mathrm{~g} / \mathrm{kg} \mathrm{DM})$ & -6 & -46 & -57 & 158 & 134 \\
\hline
\end{tabular}

' In silage: $\mathrm{pH} 3.96$; In DM (g/kg): WSC 28, lactic acid 62, acetic acid 16, ethanol 6; In total N (g/kg): ammonia $\mathrm{N} 30$, soluble $\mathrm{N} 505$.

${ }^{2} \mathrm{~A}$ mixture of barley and sugar beet pulp (8:2).

${ }^{3}$ Nitrogen free extracts.

${ }^{4}$ Efficient protein degradability, rate of passage $0.03 / \mathrm{h}$ for barley and 0.04 for RSM.

${ }^{5}$ Calculated from D-value determined in sheep for silage and from feed table digestibility coefficients for the concentrates.

${ }^{6}$ The values determined by nylon bag method for concentrates and from feed tables (Tuori et al. 1995) for silage.

${ }^{7}$ Calculated using determined EPD values for the concentrates and a value of 0.85 for silage.

od for the concentrate feeds and a value of 0.85 for silage (Tuori et al. 1995) or using EPD values from Finnish feed tables (Tuori et al. 1995) for all feeds.

The data were analysed with general linear models of the Statistical Analyses System (SAS Institute 1989). The model included the effects of block, cow (block), period, treatment and carry-over. The results for the production parameters are adjusted for the carry-over effects although all these effects were non-significant and negligible. The treatment effects were further separated into single degree comparisons of effects of barley treatment, RSM supplementation, RSM treatment, interaction between barley and RSM supplementation, and interaction between barley treatment and RSM treatment. Data from the rumen fermentation study was subjected to a split-plot analysis of variance for repeated measurements.

\section{Results}

The silage fed was of good fermentation quality in terms of low $\mathrm{pH}$, low concentrations of fermentation acids and small proportion of ammonia $\mathrm{N}$ in total $\mathrm{N}$ (Table 1). Despite the relatively low crude protein content in the silage, the Dvalue determined in sheep was fairly high $(681 \mathrm{~g}$ digestible $\mathrm{OM} / \mathrm{kg}$ DM). Treatment of barley increased NDF content markedly, and also ADF content of the energy supplement. The treatment of both barley and RSM decreased ruminal protein degradability, and consequently increased calculated AAT values.

The results for feed intake and calculated ME and AAT consumption are shown in Table 2. Silage $\mathrm{DM}$ intake was higher $(\mathrm{P}<0.001)$ with the UB diets than the TB diets (11.14v. 10.27 kg/d). Compared with the control diets, both UR and 


\section{AGRICULTURAL AND FOOD SCIENCE IN FINLAND}

Vol. 5 (1996): 399-412.

Table 2. Feed intake and calculated ME and AAT consumption in cows receiving grass silage with supplements based untreated barley (UB) or treated barley (TB), both given without protein supplementation (control), with untreated RSM or treated RSM.

\begin{tabular}{|c|c|c|c|c|c|c|c|c|c|c|c|c|}
\hline & \multicolumn{2}{|c|}{ Control } & \multicolumn{2}{|c|}{ Untreated RSM } & \multicolumn{2}{|c|}{ Treated RSM } & \multirow[b]{2}{*}{ SEM } & \multicolumn{5}{|c|}{ Significance of effect ${ }^{\prime}$} \\
\hline & UB & TB & UB & TB & UB & TB & & B & $\mathrm{R}$ & RT & $\mathrm{B} \times \mathrm{R}$ & $\mathrm{B} \times \mathrm{RT}$ \\
\hline \multicolumn{13}{|l|}{ Intake (kg DM/d) } \\
\hline Silage & 10.61 & 9.36 & 11.20 & 10.84 & 11.61 & 10.62 & 0.139 & $* * *$ & $* * *$ & NS & * & NS \\
\hline Concentrate & 8.83 & 8.77 & 8.79 & 8.78 & 8.84 & 8.80 & & & & & & \\
\hline Total & 19.44 & 18.13 & 19.99 & 19.62 & 20.45 & 19.42 & 0.140 & $* * *$ & $* * *$ & NS & * & NS \\
\hline $\mathrm{ME}(\mathrm{MJ} / \mathrm{d})^{2}$ & 221.8 & 209.3 & 222.6 & 220.8 & 229.4 & 218.6 & 1.55 & $* * *$ & $* * *$ & NS & $*$ & $*$ \\
\hline $\mathrm{ME}(\mathrm{MJ} / \mathrm{d})^{3}$ & 199.8 & 186.1 & 206.1 & 203.2 & 213.0 & 200.4 & 1.62 & $* * *$ & $* * *$ & NS & o & $* *$ \\
\hline Difference (MJ/d) & 22.0 & 23.1 & 16.5 & 17.6 & 16.5 & 18.2 & 0.77 & o & $* * *$ & NS & NS & NS \\
\hline AAT $(\mathrm{g} / \mathrm{d})^{4}$ & 1747 & 1690 & 1824 & 1841 & 1947 & 1896 & 11.8 & $* *$ & $* * *$ & $* * *$ & o & $*$ \\
\hline $\operatorname{AAT}(\mathrm{g} / \mathrm{d})^{5}$ & 1736 & 1636 & 1848 & 1831 & 1908 & 1821 & 11.8 & $* * *$ & $* * *$ & o & * & * \\
\hline $\operatorname{PBV}(\mathrm{g} / \mathrm{d})^{4}$ & -468 & -551 & -109 & -182 & -184 & -253 & 1.3 & $* * *$ & $* * *$ & $* * *$ & $* * *$ & NS \\
\hline
\end{tabular}

' Significance of orthogonal contrasts: $\mathrm{B}=$ effect of barley treatment, R = effect of RSM supplementation, RT = effect of RSM treatment, B x R =interaction between barley treatment and RSM supplementation and B $\times$ RT = interaction between barley treatment and RSM treatment.

o $\mathrm{P}<0.10,{ }^{*} \mathrm{P}<0.05,{ }^{* *} \mathrm{P}<0.01,{ }^{* * *} \mathrm{P}<0.001$.

${ }^{2}$ Calculated using D-value determined in sheep for silage and feed table values for concentrates.

${ }^{3}$ Calculated from the intake of digestible OM determined in cows using AIA as an internal marker.

${ }^{4}$ Calculated using determined EDP values for the concentrates of 0.85 for silage.

${ }^{5}$ Calculated using for all feeds EDP values from feed tables (Tuori et al. 1995).

TR diets increased $(\mathrm{P}<0.001)$ silage $\mathrm{DM}$ intake (9.99 v. 11.02 and 11.11 (SEM 0.10) kg/d). The response in silage DM intake to RSM supplementation was greater $(1.4 v .0 .8 \mathrm{~kg} / \mathrm{d})$ with $\mathrm{TB}$ than with UB (barley x RSM, P<0.05). The differences in calculated ME intake showed the similar patterns to those in silage and total DM intake. Inclusion of RSM increased ME intake more with TB than UB (10.4v. $4.2 \mathrm{MJ} / \mathrm{d}$, $\mathrm{P}<0.05)$. Moreover, the adverse effect of TB on ME intake was greater $(\mathrm{P}<0.05)$ with treated RSM than with untreated RSM (10.8v. 1.8 MJ/ d). On average, ME intake was $19.4 \mathrm{MJ} / \mathrm{d}$ smaller when estimated from DOM intake than when calculated from silage D-value and from chemical composition and feed table digestibility coefficients for the concentrates. Including RSM in the diet decreased this difference by $5.4 \mathrm{MJ} / \mathrm{d}$ $(\mathrm{P}<0.001)$. Because of reduced DM intake, the supply of AAT was smaller with TB diets than UB diets even when the lower ruminal degradability of TB was considered. RSM supplemen- tation increased $(\mathrm{P}<0.001)$ estimated AAT intake, and RSM treatment further increased AAT intake when the values were based on measured ruminal protein degradability.

Despite reduced feed intake, barley treatment did not affect milk yield (Table 3). However, energy-corrected milk (ECM) yield was higher $(\mathrm{P}<0.01)$ in cows given $\mathrm{UB}$ than in those given TB (29.3 v. $28.4 \mathrm{~kg} / \mathrm{d})$. The decrease in ECM yield was smaller $(\mathrm{P}<0.05)$ when $\mathrm{RSM}$ was included in the diet $(0.5 v .1 .8 \mathrm{~kg} / \mathrm{d})$. Barley treatment decreased $(\mathrm{P}<0.001)$ milk fat content $(44.1$ $v .41 .1 \mathrm{~g} / \mathrm{kg})$ and fat yield (1237v. $1154 \mathrm{~g} / \mathrm{d})$, and increased $(\mathrm{P}<0.05)$ milk protein content $(31.8 v .32 .2 \mathrm{~g} / \mathrm{kg})$ but not protein yield $(889 v$. $897 \mathrm{~g} / \mathrm{d})$. RSM increased milk yield (26.7 v. 28.9 $\mathrm{kg} / \mathrm{d} ; \mathrm{P}<0.001)$, milk protein content (31.7 v. 32.2 $\mathrm{g} / \mathrm{kg} ; \mathrm{P}<0.01)$ and protein yield $(838 v .921 \mathrm{~g} / \mathrm{d}$; $\mathrm{P}<0.001)$. Including RSM in the diet resulted in a smaller $(\mathrm{P}<0.05)$ decrease in fat yield in the response to barley treatment $(57 v .136 \mathrm{~g} / \mathrm{d})$. The effects of treatment of RSM on milk yield, milk 
Huhtanen, $P . \&$ Heikkilä, T. Treated barley and rapeseed meal for dairy cows

Table 3. Effects of supplements on milk production in cows receiving grass silage with supplements based on untreated barley (UB) or treated barley (TB) both given without protein supplementation (control), with untreated RSM or treated RSM.

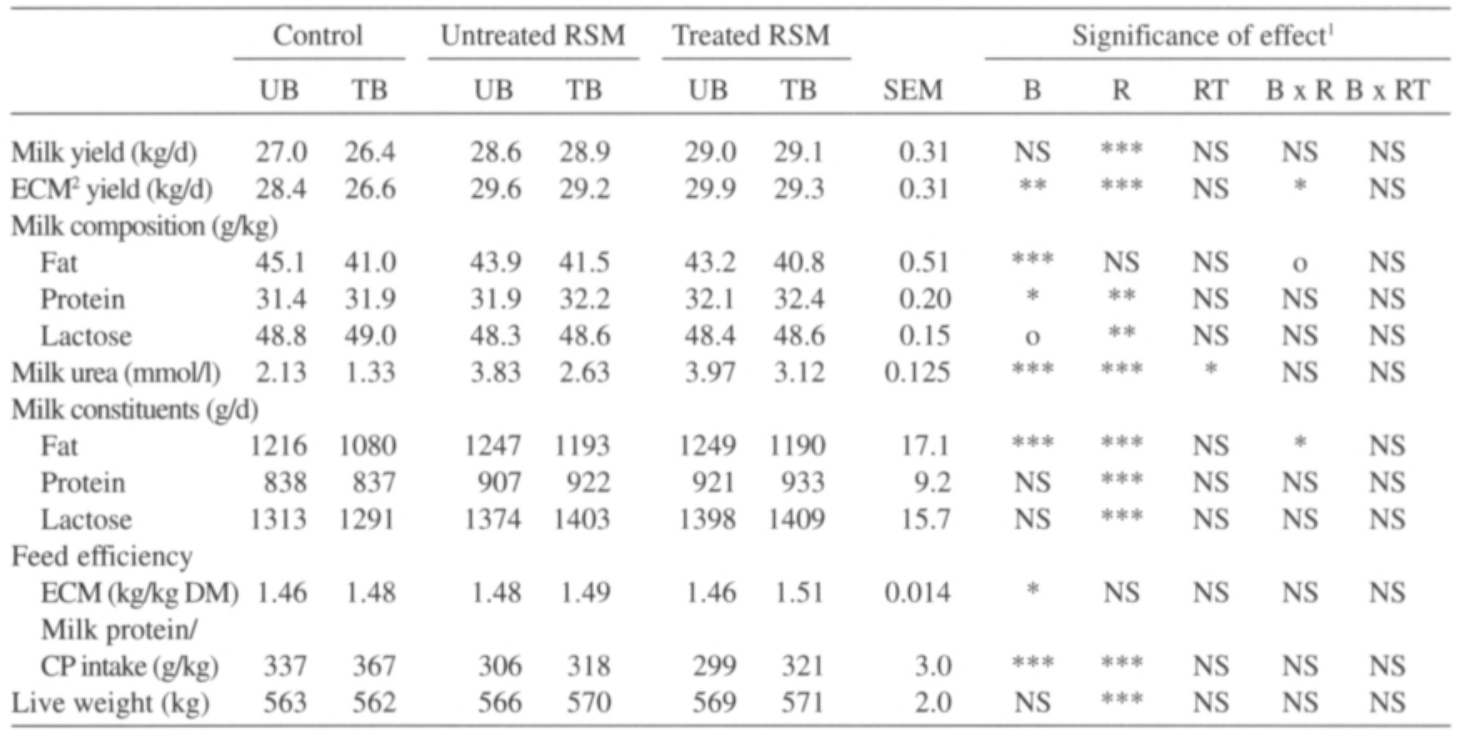

' Significance of orthogonal contrasts: $\mathrm{B}=$ effect of barley treatment, R = effect of RSM supplementation, RT = effect of RSM treatment, B x R = interaction between barley treatment and RSM supplementation and B $\times$ RT = interaction between barley treatment and RSM treatmen

o $\mathrm{P}<0.10,{ }^{*} \mathrm{P}<0.05,{ }^{* *} \mathrm{P}<0.01,{ }^{* * *} \mathrm{P}<0.001$.

${ }^{2} \mathrm{ECM}=$ energy corrected milk (Sjaunja et al. 1990).

protein content and yield $(0.3 \mathrm{~kg} / \mathrm{d}, 0.2 \mathrm{~g} / \mathrm{kg}$ and $13 \mathrm{~g} / \mathrm{d}$ ) were all small and non-significant. Feeding TB instead of UB decreased $(\mathrm{P}<0.001)$ milk urea content $(3.32$ v. $2.27 \mathrm{mmol} / \mathrm{l})$, whilst treatment of RSM increased $(\mathrm{P}<0.05)$ milk urea content $(3.23$ v. $3.54 \mathrm{mmol} / \mathrm{l})$. Feed efficiency measured in terms of ECM per $\mathrm{kg}$ DM intake was improved $(\mathrm{P}<0.05)$ by barley treatment. Barley treatment improved and RSM supplementation reduced the efficiency of feed protein utilization. Treatment of RSM had no effect on protein utilization. The mean live weight was greater $(\mathrm{P}<0.001)$ in cows given RSM than in those fed without protein supplement.

Replacing UB with TB in the supplement had no effect on the proportion of short chain fatty acids $\left(\mathrm{C}_{4}-\mathrm{C}_{14: 1}\right)$ in milk, but the proportions of butyric $\left(\mathrm{C}_{4}\right)$ and caproic acid $\left(\mathrm{C}_{6}\right)$ acids were higher with UB than TB (Table 4). The proportion of palmitic acid $\left(\mathrm{C}_{16: 0}\right)$ was higher $(\mathrm{P}<0.001)$ with UB than with TB $(315 v .300 \mathrm{~g} / \mathrm{kg})$, while the proportion of oleic acid $\left(\mathrm{C}_{18: 1}\right)$ was lower (178 v. $185 \mathrm{~g} / \mathrm{kg} ; \mathrm{P}<0.01)$. The greatest relative increase with treatment of barley (23.4 to $29.5 \mathrm{~g} /$ $\mathrm{kg} ; \mathrm{P}<0.001$ ) occurred in the proportion of linolic acid $\left(\mathrm{C}_{18: 2}\right)$. RSM supplementation increased $(\mathrm{P}<0.01)$ the proportion of $\mathrm{C}_{18: 1}$ and decreased $(\mathrm{P}<0.01)$ that of $\mathrm{C}_{18: 2}$. RSM treatment had no effect on milk fatty acid composition.

The increase in OM digestibility in response to RSM supplementation was small (Table 5), although statistically significant $(\mathrm{P}<0.01)$. Treatment of barley had no effect on OM digestibility but CP digestibility was decreased $(0.646 v$. $0.606 ; \mathrm{P}<0.001)$. NDF digestibility was higher in cows given TB than in those given UB $(0.675$ v. 0.660 ), but the digestibility of crude fibre was lower $(0.644 v .0 .672)$ with TB than with UB. The response of crude fibre digestibility to RSM supplementation was greater $(\mathrm{P}<0.05)$ with $\mathrm{TB}$ 
Vol. 5 (1996): 399-412.

Table 4. Effects of supplements on milk fatty acid composition $(\mathrm{g} / \mathrm{kg})$ in cows receiving grass silage with supplements based on untreated barley (UB) or treated barley (TB), both given without protein supplementation (control), with untreated RSM or treated RSM.

\begin{tabular}{|c|c|c|c|c|c|c|c|c|c|c|c|c|}
\hline \multirow{2}{*}{$\begin{array}{l}\text { Fatty } \\
\text { acid }\end{array}$} & \multicolumn{2}{|c|}{ Control } & \multicolumn{2}{|c|}{ Untreated RSM } & \multicolumn{2}{|c|}{ Treated RSM } & \multirow[b]{2}{*}{ SEM } & \multicolumn{5}{|c|}{ Significance of effect ${ }^{1}$} \\
\hline & UB & ТВ & UB & TB & UB & TB & & B & $\mathbf{R}$ & RT & $\mathrm{B} \times \mathrm{R}$ & $x$ RT \\
\hline $\mathrm{C}_{4}$ & 57.1 & 51.3 & 54.0 & 51.0 & 55.5 & 50.1 & 1.04 & $* * *$ & NS & NS & NS & NS \\
\hline $\mathrm{C}_{6}$ & 31.1 & 30.0 & 30.4 & 29.7 & 31.1 & 29.7 & 0.45 & $*$ & NS & NS & NS & NS \\
\hline $\mathrm{C}_{8}$ & 17.1 & 17.7 & 17.3 & 17.7 & 17.8 & 17.9 & 0.28 & NS & NS & NS & NS & NS \\
\hline $\mathrm{C}_{10}^{\circ}$ & 38.9 & 42.3 & 40.3 & 41.7 & 41.4 & 42.7 & 0.73 & $* *$ & NS & NS & NS & NS \\
\hline $\mathrm{C}_{12}$ & 46.0 & 49.9 & 47.5 & 48.5 & 48.7 & 50.7 & 1.06 & * & NS & NS & NS & NS \\
\hline $\mathrm{C}_{14}$ & 144.3 & 143.9 & 144.3 & 143.1 & 147.8 & 142.7 & 1.28 & * & NS & NS & NS & NS \\
\hline $\mathrm{C}_{14.1}$ & 20.1 & 19.7 & 20.1 & 20.5 & 20.5 & 20.5 & 0.39 & NS & NS & NS & NS & NS \\
\hline $\mathrm{C}_{4} \mathrm{C}_{14: 4}$ total & 355.5 & 355.5 & 353.8 & 352.3 & 362.8 & 354.9 & 3.96 & NS & NS & NS & NS & NS \\
\hline $\mathrm{C}_{1600}$ & 322.0 & 306.1 & 313.8 & 298.0 & 309.5 & 296.1 & 3.97 & *** & * & NS & NS & NS \\
\hline$C_{16-1}$ & 25.6 & 25.8 & 23.6 & 23.6 & 23.9 & 23.5 & 0.25 & NS & $* * *$ & NS & NS & NS \\
\hline$C_{18-0}$ & 91.5 & 89.1 & 94.8 & 95.2 & 91.3 & 93.4 & 1.76 & NS & NS & o & NS & NS \\
\hline$C_{18-1}$ & 173.0 & 178.6 & 180.5 & 188.9 & 180.1 & 188.9 & 2.80 & $* *$ & ** & NS & NS & NS \\
\hline$C_{18,2}$ & 24.1 & 31.2 & 23.0 & 28.6 & 23.0 & 28.7 & 0.47 & *** & ** & NS & NS & NS \\
\hline
\end{tabular}

' Significance of orthogonal contrasts: $\mathrm{B}=$ effect of barley treatment, $\mathrm{R}=$ effect of RSM supplementation, RT $=$ effect of RSM treatment, B x R = interaction between barley treatment and RSM supplementation and B $\times$ RT = interaction between barley treatment and RSM treatment.

o $\mathrm{P}<0.10, * \mathrm{P}<0.05, * * \mathrm{P}<0.01, * * * \mathrm{P}<0.001$.

than UB $(0.047 v .0 .019)$. DM content in faeces was higher $(142 v .125 \mathrm{~g} / \mathrm{kg} ; \mathrm{P}<0.001)$ in cows fed UB than in those fed TB.
Treatment of barley decreased ruminal ammonia $\mathrm{N}$ concentration and the molar proportion of isovalerate of total VFA (Table 6). The ratio

Table 5. Effects of supplements on diet digestibility in cows receiving grass silage with supplements based on untreated barley (UB) or treated barley (TB) both, given without protein supplementation (control), with untreated RSM or treated RSM.

\begin{tabular}{|c|c|c|c|c|c|c|c|c|c|c|c|c|}
\hline & \multicolumn{2}{|c|}{ Control } & \multicolumn{2}{|c|}{ Untreated RSM } & \multicolumn{2}{|c|}{ Treated RSM } & \multirow[b]{2}{*}{ SEM } & \multicolumn{5}{|c|}{ Significance of effect ${ }^{\prime}$} \\
\hline & UB & TB & UB & TB & UB & TB & & B & $\mathrm{R}$ & RT & $\mathrm{B} \times \mathrm{R}$ & x RT \\
\hline DM & 0.701 & 0.695 & 0.710 & 0.706 & 0.713 & 0.704 & 0.0027 & $* *$ & $* * *$ & NS & NS & NS \\
\hline $\mathrm{OM}$ & 0.721 & 0.716 & 0.731 & 0.728 & 0.734 & 0.727 & 0.0028 & * & $* * *$ & NS & NS & NS \\
\hline Nitrogen & 0.608 & 0.572 & 0.669 & 0.626 & 0.665 & 0.622 & 0.0029 & *** & *** & NS & NS & NS \\
\hline Ether extract & 0.674 & 0.685 & 0.683 & 0.696 & 0.686 & 0.690 & 0.0035 & $* *$ & ** & NS & NS & NS \\
\hline Crude fibre & 0.661 & 0.614 & 0.671 & 0.661 & 0.685 & 0.657 & 0.0063 & $* * *$ & *** & NS & $*$ & NS \\
\hline NFE & 0.754 & 0.766 & 0.760 & 0.769 & 0.761 & 0.770 & 0.0030 & $* * *$ & NS & NS & NS & NS \\
\hline NDF & 0.649 & 0.663 & 0.660 & 0.679 & 0.671 & 0.685 & 0.0045 & $* *$ & $* * *$ & NS & NS & NS \\
\hline \multicolumn{13}{|l|}{$\operatorname{MFOM}^{2}(\mathrm{~g} / \mathrm{kg}$} \\
\hline DMI) & 115.4 & 111.3 & 108.3 & 107.3 & 109.5 & 111.8 & 1.50 & NS & $* *$ & NS & NS & NS \\
\hline
\end{tabular}

' Significance of orthogonal contrasts: $\mathrm{B}=$ effect of barley treatment, $\mathrm{R}=$ effect of RSM supplementation, RT = effect of RSM treatment, B x R = interaction between barley treatment and RSM supplementation and B $\times$ RT $=$ interaction between barley treatment and RSM treatment.

o $\mathrm{P}<0.10, * \mathrm{P}<0.05$, ** $\mathrm{P}<0.01, * * * \mathrm{P}<0.001$.

${ }^{2}$ Metabolic faecal OM (grammes of OM - NDF in faeces per kg DM intake) 
Huhtanen, P. \& Heikkilä, T. Treated barley and rapeseed meal for dairy cows

Table 6. Effects of barley treatment on rumen fermentation in cows given grass silage.

\begin{tabular}{|c|c|c|c|c|c|c|c|c|}
\hline \multirow[t]{2}{*}{ Barley } & \multirow[t]{2}{*}{$\mathrm{pH}$} & $\mathrm{NH}_{4}-\mathrm{N}$ & VFA & Acetate & Propionate & Butyrate & Isovalerate & $(\mathrm{Ac}+\mathrm{Bu}) / \mathrm{Pr}$ \\
\hline & & \multicolumn{2}{|c|}{$(\mathrm{mmol} / \mathrm{L})$} & \multicolumn{4}{|c|}{$(\mathrm{mmol} / \mathrm{mol})$} & \\
\hline Untreated & 6.17 & 7.0 & 143 & 676 & 177 & 123 & 10.1 & 4.54 \\
\hline Treated & 6.13 & 3.2 & 139 & 660 & 187 & 131 & 7.5 & 4.26 \\
\hline SEM & 0.02 & 0.69 & 2.1 & 4.6 & 6.3 & 1.6 & 0.32 & 0.10 \\
\hline Significance & NS & o & NS & NS & NS & o & * & NS \\
\hline
\end{tabular}

o $\mathrm{P}<0.10,{ }^{*} \mathrm{P}<0.05,{ }^{* *} \mathrm{P}<0.01,{ }^{* * *} \mathrm{P}<0.001$.

of lipogenic to glucogenic VFA tended to be lower in cows given TB than in those given UB. Faster rate of gas production at an early stage of fermentation in vitro (Fig. 1) from TB than from UB indicates that the treatment increased the rate of starch fermentation.

Milk energy yield was lower $(\mathrm{P}<0.001)$ with TB than UB but it was increased by RSM supplementation (Table 7). Inclusion of RSM in the diet improved $(\mathrm{P}<0.05)$ the utilization of surplus ME for milk production when ME intake was estimated from feed table values. However, when the estimated ME intake was based on DOM, RSM did not affect ME utilization, but barley

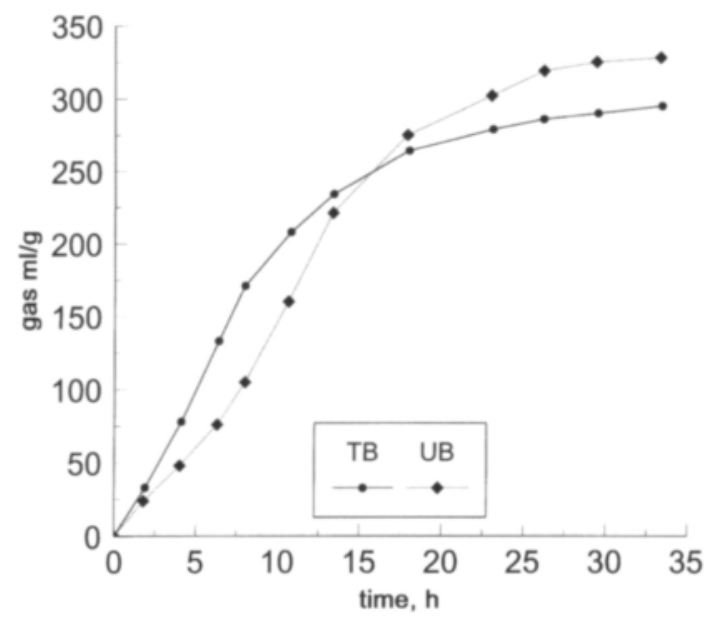

Fig. 1. Effect of untreated (UB) and heat-moisture-treated barley (TB) on cumulative gas production in vitro. treatment improved $(\mathrm{P}<0.01)$ it. Barley treatment increased and RSM supplementation decreased the efficiency of AAT utilization irrespective of the method of calculating the AAT supply. RSM treatment had no effect on calculated AAT utilization when the same EPD values $(650 \mathrm{~g} / \mathrm{kg})$ were used for untreated and treated RSM, but when the EPD values were determined by nylon bag method, the efficiency of AAT utilization was lower $(\mathrm{P}<0.001)$ in cows given treated RSM than in those given untreated RSM.

\section{Discussion}

\section{Effect of RSM supplementation}

Feeding RSM containing diets caused the welldocumented increase in silage DM intake when CP content of the supplement is increased (see Thomas and Rae 1988, Chamberlain et al. 1989). In the present study the response was $0.44 \mathrm{~kg}$ per $10 \mathrm{~g} / \mathrm{kg}$ increase in dietary CP content, similar to that reported recently with RSM supplementation (Huhtanen et al. 1995) and earlier with soybean meal supplementation (Chamberlain et al. 1989). Tuori (1992) reported a mean response of $0.27 \mathrm{~kg}$ in total DM intake when dietary CP content was increased by $10 \mathrm{~g} / \mathrm{kg}$ with RSM supplementation. The greater response to RSM that we found with treated barley may be related to 


\section{AGRICULTURAL AND FOOD SCIENCE IN FINLAND}

Vol. 5 (1996): 399-412.

Table 7. Effect of supplements on the utilization of ME and AAT of the cows given grass silage.

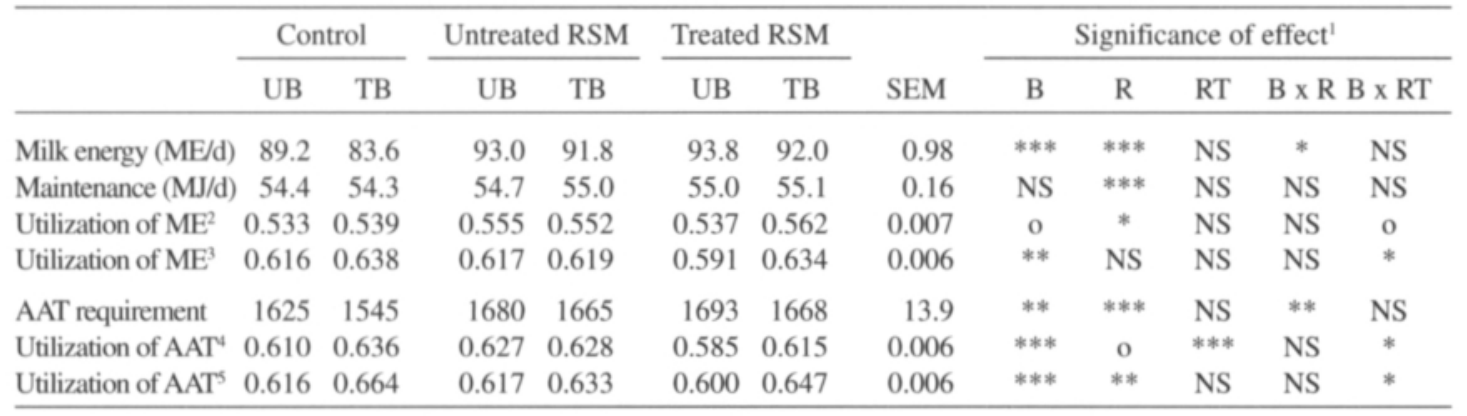

' Significance of orthogonal contrasts: $\mathrm{B}=$ effect of barley treatment, R = effect of RSM supplementation, RT = effect of RSM treatment, B x R = interaction between barley treatment and RSM supplementation and B $\times$ RT = interaction between barley treatment and RSM treatment.

o $\mathrm{P}<0.10,{ }^{*} \mathrm{P}<0.05,{ }^{* *} \mathrm{P}<0.01,{ }^{* * *} \mathrm{P}<0.001$.

${ }^{2} \mathrm{ME}$ intake calculated using D-value determined in sheep for silage and feed table values for concentrates.

${ }^{3}$ Calculated from the intake of digestible OM determined in cows using AIA as an internal marker.

${ }^{4}$ Calculated using EDP values determined by nylon-bag method for the concentrates and a value of 0.85 for silage.

${ }^{5}$ Calculated using EDP values from feed tables (Tuori et al. 1995) for all feeds.

more limited supply of rumen degradable feed protein from treated than from untreated barley. Lower ruminal protein degradability with treated barley, together with the lower ruminal ammonia concentration, support this suggestion.

Increased silage DM intake in cows given protein supplementation has often been attributed to increased cell wall digestibility in the rumen (Oldham 1984). In the present study, RSM supplementation slightly increased OM digestibility $(0.719 v .0 .730)$, but the difference is too small to explain an increase of $1.08 \mathrm{~kg} \mathrm{DM} / \mathrm{d}$ in silage intake. For example, in the data reviewed by Huhtanen (1993) the mean increase in silage DM intake was $0.15 \mathrm{~kg}$ per $10 \mathrm{~g} / \mathrm{kg}$ increase in silage D-value. In some studies (Tuori 1992, Huhtanen et al. 1995), RSM has increased DM intake without affecting diet digestibility. This suggests that factors other than improved digestibility are involved. Khalili et al. (1995) observed a greater increase in silage DM intake with duodenal than with ruminal infusion of casein. Choung and Chamberlain (1992) also reported an increase in silage DM intake in response to duodenal casein infusion. These observations suggest that the effects of protein supplementa- tion are mediated mainly by metabolic mechanisms, probably related to protein or protein to energy ratio.

The present mean milk and protein yield responses of 3.8 and $0.15 \mathrm{~g}$ per $1 \mathrm{~g} /$ day increase in $\mathrm{CP}$ intake are similar to those in our recent study with RSM (Huhtanen et al. 1995) and in studies of Chamberlain et al. (1989) with soybean meal. The increase in milk yield was $0.30 \mathrm{~kg}$ per $1 \mathrm{MJ}$ increase in ME intake calculated from feed table values. This is greater than the $0.194 \mathrm{~kg}$ ECM/MJ ME in Finnish feeding recommendations (Tuori et al. 1995) and considerably greater than the response of approximately 0.10 to increased concentrate intake in studies conducted at this institute (Heikkilä et al. and Rinne et al., unpublished observations). Calculated efficiency of the utilization of ME for milk production was improved by the protein supplementation in the present study, in agreement with earlier calculations (Chamberlain et al. 1989, Huhtanen 1993). However, calculation of ME utilization from production experiments is susceptible to a number of errors. Calorimetric studies (e.g. Whitelaw et al. 1986) do not suggest an improvement in ME utilization in cows given 


\section{AGRICULTURAL AND FOOD SCIENCE IN FINLAND}

Huhtanen, P. \& Heikkilä, T. Treated barley and rapeseed meal for dairy cows

protein supplements. Greater mean live weight and live weight gain in cows given RSM supplements indicate that mobilization of body tissues was not increased. However, live weight change is likely to be a poor indicator of cow's energy balance, especially in change-over experiments. Whitelaw et al. (1986) observed that when the protein status of the cows was poor, they mobilized mainly body protein. When the protein supply was increased by abomasal casein infusion, energy retention was not affected, but fat mobilization increased at the expense of increased protein retention. These changes in the composition of mobilized body tissues without changes in energy retention can result in considerable error when the energy balance is estimated from live weight change, and may explain the greater live weight gain in cows given RSM in the present study. Greater live weight in cows given RSM supplements may partly be related to greater feed intake and increased weight of digesta in the gastro-intestinal tract.

In agreement with calorimetric studies (Whitelaw et al. 1986), the efficiency of ME utilization was not found to be affected by RSM when the supply of ME was estimated from DOM intake. RSM supplementation increased ME intake by 7.3 MJ/d when estimated from digestibility coefficients in sheep, while the corresponding increase was $12.7 \mathrm{MJ} / \mathrm{d}$ when the estimates were based on DOM determined in the cows. With these values, the marginal response in milk yield decreased from 0.30 to $0.19 \mathrm{~kg} /$ MJ ME, suggesting that increased DM intake and a smaller depression in digestibility at high level of feeding accounted for the increase in milk yield.

\section{Effect of RSM treatment}

In agreement with studies of Huhtanen (1991) and Tuori (1992), reducing ruminal protein degradability by physical processing had no effect on milk production. In contrast to this, Bertilsson et al. (1994) reported positive effect of treatment of RSM on milk production at low level but not at high level of inclusion. However, in other Swedish studies reviewed by Bertilsson (1990), no responses were observed. The present results are also in line with findings of Rae et al. (1983), Castle and Watson (1984) and Small and Gordon (1990) who reduced ruminal degradability of rapeseed meal or soybean meal by formaldehyde treatment. Where our calculations were based on EPD values determined by nylon bag method, the marginal response in milk protein yield was $0.50 \mathrm{~g} / \mathrm{g}$ AAT when the supply was increased by including RSM in the diet, but only 0.08 when the supply was increased by reducing ruminal protein degradability of RSM. The corresponding responses were 0.50 and 0.54 when the AAT supply was estimated using the EPD values from Finnish feed tables. In line with the present study, Small and Gordon (1990) concluded that changes in ruminal protein degradability did not elicit the same production responses as those achieved by increasing the total supply of protein.

The lack of effect of treated RSM compared with untreated RSM may be related to reduced microbial protein production in the rumen. Although the calculated PBV was more negative with treated than with untreated RSM, similar DM intake and digestibility together with rather high $(7.0 \mathrm{mmol} / \mathrm{l})$ rumen ammonia $\mathrm{N}$ concentration in cannulated cows suggest that microbial $\mathrm{N}$ synthesis was not limited by rumen ammonia $\mathrm{N}$. When Robinson et al. (1994) gradually replaced untreated RSM with treated RSM in the supplement, they found no differences in rumen ammonia $\mathrm{N}$ concentration between the treatments, and numerically the efficiency of microbial protein synthesis decreased with decreasing ruminal degradability of RSM protein. No increase in duodenal flow of non-ammonia $\mathrm{N}$ flow was obtained because of reduced efficiency of microbial synthesis. Voigt and Piatkowski (1991) similarly reported that decreasing ruminal degradability of protein supplements decreases the efficiency of microbial protein synthesis, thereby partly compensating the increased flow of feed amino acids to the small intestine. Heat treatment can decrease the availability of amino 


\section{AGRICULTURAL AND FOOD SCIENCE IN FINLAND}

Vol. 5 (1996): 399-412.

acids. Lysine content was found to be considerably lower in treated than in untreated RSM (Tuori 1992, Moshtagni Nia and Ingalls 1995). In agreement with the observations of Tuori (1992), treatment of RSM did not decrease N digestibility in vivo compared with untreated RSM. However, disappearance of amino acids from the small intestine does not mean that the $\alpha$-amino $\mathrm{N}$ can be utilized for protein synthesis (Hurrel and Finot 1985).

\section{Effect of barley treatment}

In previous studies, expanding (Prestløkken, 1994) and roasting (Robinson and McNiven 1994) decreased ruminal degradability of barley protein, and the current experiment confirms that ruminal degradability of barley protein can be reduced by heat treatment. Heat treatment of barley increased the proportion of NDF-N from 200 to 460 and that of ADF-N from 36 to $132 \mathrm{~g} / \mathrm{kg}$ total $\mathrm{N}$, which may explain the reduced $\mathrm{N}$ digestibility. The increase of $1.9 \mathrm{~g} / \mathrm{kg} \mathrm{DM}$ in ADF-N content of the concentrate corresponds well with the mean decrease of 0.04 in $\mathrm{N}$ digestibility. Robinson and McNiven (1994) also reported a greater ADF-N content in roasted barley than in raw barley. In contrast to their observations with roasted barley, heat treatment in our study increased the rate of energy fermentation as judged from faster rate of gas production in vitro. The changes in fermentation characteristics in TB can be expected to improve the synchronization of energy and protein release in the rumen. However, practical attempts have not been very successful in demonstrating the beneficial effects of synchronized energy and protein release in the rumen (Chamberlain and Choung 1995, Van Vuuren et al. 1995).

Feeding TB rather than UB decreased silage DM intake markedly, but including RSM in the diet partially alleviated this adverse effect. This suggests limited supply of rumen degradable $\mathrm{N}$ to be the main reason for reduced silage DM intake in cows given TB. Robinson and McNiven (1994) reported that roasting of barley has no effect on total DM intake, but dietary crude protein content was much higher in their study than in ours. Reduced ECM yield in cows given treated barley was associated only with a lower fat yield, while the yields of protein and lactose were similar to those observed with UB. Using a formaldehyde reagent to reduce degradability of barley and oats, Kassem et al. (1987) and Martin and Thomas (1988) observed broadly similar changes in milk production and milk composition to those found in the present study. Similar repartitioning of energy between milk components was observed when the ratio of lipogenic to glucogenic VFA was decreased in a VFA mixture infused into the rumen (Miettinen and Huhtanen 1996). The results of our rumen fermentation study are in line with this finding, although the difference in VFA ratio was too small to cause a depression of $3 \mathrm{~g} / \mathrm{kg}$ in milk fat content. A smaller proportion of $\mathrm{C}_{4}$ and $\mathrm{C}_{6}$ fatty acids in milk of cows fed TB also suggests that the supply of propionate was greater from TB than from UB (Hurtaud et al. 1993, Miettinen and Huhtanen 1996).

The utilization of feed protein for milk protein synthesis was improved by barley treatment irrespective of the method of calculation. This may be explained by increased flow of feed or microbial protein to the small intestine. Amino acid composition of barley protein is considered relatively poor because of low content of lysine. In cows fed grass silage-based diets, no differences in milk protein yield were observed between isonitrogenous supplements of fishmeal and barley protein (Blauwiekel et al. 1992) and between RSM and barley protein (Jaakkola et al. unpublished), suggesting that barley protein could be a valuable supplement for dairy cows. When ruminal degradability of feed protein is reduced, utilization of feed protein for milk protein synthesis can be improved only if the efficiency of microbial protein synthesis is not decreased. Microbial protein synthesis was not measured in the present study, but reduced rumen ammonia $\mathrm{N}$ concentration and reduced proportion of isovalerate in rumen VFA in cows given TB suggest either decreased proteolysis or 


\section{AGRICULTURAL AND FOOD SCIENCE IN FINLAND}

Huhtanen, P. \& Heikkilä, T. Treated barley and rapeseed meal for dairy cows

increased utilization for microbial growth. It is also possible that increased glucose production from propionate in cows given treated barley increased the efficiency of the utilization of amino acids for milk protein synthesis.

The effects of barley treatment on milk fatty acid composition were small although statistically significant in some cases. Lower proportion, and especially lower yield of palmitic acid, may reflect reduced supply of acetate and $\beta$-hydroxybutyrate from rumen fermentation in cows given treated barley. Increased proportions of oleic and linolic acids suggest that barley treatment decreased the biohydrogenation of unsaturated fatty acids in the rumen.

\section{Conclusions}

Silage intake and production of milk components increased when dietary crude protein content was increased by replacing a mixture of barley and unmolassed sugar beet pulp with rapeseed meal. However, decreasing ruminal degradability of protein by heat-moisture treatment of rapeseed meal did not elicit any further response. To explain these different marginal responses to increased amino acid supply from increased protein content and reduced ruminal degradability of the supplement will require further study. Heat-moisture treatment of barley proved to be an attractive method to decrease milk fat content and at the same time to increase protein content slightly. However, the economic benefits of treatment are negligible since silage intake is decreased and milk production is not improved.

Acknowledgements. The authors are grateful to Raisio Ltd. for partial financial support. We thank the staff of Lintupaju dairy barn of Jokioinen Estate for technical assistance and Vesa Toivonen and his staff for the laboratory analyses. Appreciation is expressed to Seppo Ahvenjärvi for carrying out the measurements of gas production.

\section{References}

Antila, V. \& Kankare, V. 1983. Fatty acid composition of milk lipids. Milchwissenchaft 38: 478-480.

Barker, S.B. \& Summerson, W.H. 1941. The colorimetric determination of lactic acid in biological materials. Journal of Biological Chemistry 138: 537-554.

Bertilsson, J. 1990. Response of dietary AAT density on milk yield - review of production trials in Sweden. Fat and Protein Feeding to the Dairy Cow. Seminar 1516.10.1990, Eskilstuna, Sweden. p.73-79.

- , Gonda, H-L. \& Lindberg, J.E. 1994. Effect of level and degradability of rapeseed meal in rations for dairy cows. 1. Animal performance. Acta Agriculturae Scandinavica, Section A, Animal Science 44: 222-229.

Blauwiekel, R., Huhtanen, P. \& Saastamoinen, I. 1992. Effect of fishmeal or barley protein and VFA infusions on milk yield and composition and blood metabolites. Journal of Dairy Science 75, Supplement 1: 199

Castle, M.E. \& Watson, J.N. 1984. Silage and milk production: A comparison between concentrates containing different amounts of protected protein as supplements for silage of high digestibility. Grass and Forage Science 39: 93-99.

Chamberlain, D.G. \& Choung, J.J. 1995. The importance of rate of ruminal fermentation of energy sources in diets for dairy cow. In: Cole, D.J.A. \& Garnsworthy, P.C. (eds.).
Recent Advances in Animal Nutrition. Butterworths, London. p. 1-27.

- , Martin, P.A. \& Robertson, S. 1989. Optimizing compound feed use in dairy cows with high intakes of silage. In: Haresign, W. \& Cole, D.J.A. (eds.). Recent Advances in Animal Nutrition. Butterworths, London. p. 175-193.

- , Robertson, S. \& Choung, J.J. 1993. Sugars and starch as supplements to grass silage: effects on ruminal fermentation and the supply of microbial protein to the small intestine, estimated from urinary excretion of purine derivatives, in sheep. Journal of Food Science and Agriculture 63: 189-194.

Choung, J.J. \& Chamberlain, D.G. 1992. Protein nutrition of dairy cows receiving grass silage diets. Effects on silage intake and milk production of postruminal supplements of casein or soya-protein isolate and the effects of intravenous infusions of a mixture of methionine, phenylalanine and tryptophan. Journal of the Science of Food and Agriculture 58: 307-314.

Davis, A.W. \& Hall, W.B. 1969. Cyclic change-over designs. Biometrica 56: 283-293.

Dreher, M.L., Dreher, C.J. \& Berry, J.W. 1984. Starch digestibility of foods. CRC Critical Reviews in Food Science and Nutrition 20: 47-71.

Huhtanen, P. 1991. The response to replacement of bar- 


\title{
AGRICULTURAL AND FOOD SCIENCE IN FINLAND
}

\author{
Vol. 5 (1996): 399-412.
}

ley with wheat bran and treatment of rapeseed meal in the diets of dairy cows given grass silage ad libitum. Acta Agriculturae Scandinavica. 41: 415-426.

- 1993. The effects of concentrate energy source and protein content on milk production in cows given grass silage ad libitum. Grass and Forage Science 48: 347355.

- , Jaakkola, S. \& Saarisalo, E. 1995. The effects of concentrate energy source on milk production of dairy cows given a grass silage-based diet. Animal Science 60: $31-40$.

Huida, L. 1973. Quantitative determination of volatile fatty acids from rumen sample and silage by gas-liquid chromatography. Journal of the Scientific Society of Agricultural Science in Finland 45: 483-488.

-, Väätäinen, H. \& Lampila, M. 1986. Comparison of dry matter contents in grass silage as determined by oven drying and gas chromatographic water analyses. Annales Agriculturae Fenniae 25: 215-230.

Hurrel, R.F. \& Finot, P.A. 1985. Effect of food processing on protein digestibility and amino acid availability. In: Finley, J.W. \& Hopkins, D.T. (eds.). Digestibility and Amino Acid Availability in Cereals and Oilseeds. American Association of Cereal Chemistry, St. Paul. p. 233-258. Hurtaud, C.H., Rulquin, H. \& Verite, R. 1993. Effect of infused volatile fatty acids and caseinate on milk production and coagulation in dairy cows. Journal of Dairy Science 76: 3011-3020.

Karow, R.S., Forsberg, R.A. \& Paterson, D.M. 1984. A comparison of two rapid oat-lipid extraction procedures in terms of fatty acid profile. Cereal Chemistry 61: 196197.

Kassem, M.M., Thomas, P.C, Chamberlain, D.G \& Robertson, S. 1987. Silage intake and milk production in cows given barley supplements of reduced degradability. Grass and Forage Science 42: 175-183.

Khalili, H., Huhtanen, P., Jaakkola, S. \& Varvikko, T. 1995. The effects or ruminal and duodenal casein infusion on intake of red clover silage, milk production and microbial protein synthesis. Animal Production 60: 544. Martin, P.A. \& Thomas, P.C. 1988. Dietary manipulation of yield and composition of milk: Effects of dietary inclusions of barley and oats in untreated or formaldehydetreated forms on milk fatty acid composition. Journal of the Science of Food and Agriculture 43: 145-154.

McCullough, H. 1967. The determination of ammonia in whole blood by a direct colorimetric method. Clinical Chimica Acta 17: 297-304.

Miettinen, H. \& Huhtanen, P. 1996. The effects of ruminal propionate to butyrate ratio on milk production and blood metabolites in dairy cows fed a grass silage based diet. Journal of Dairy Science 79: 851-861.

Moshtagni Nia, S.A. \& Ingalls, J.R. 1995. Influence of moist heat treatment on ruminal and intestinal disappearance of amino acids from canola meal. Journal of Dairy Science 78: 1552-1560.

Oldham, J.D. 1984. Protein energy relationships in dairy cows. Journal of Dairy Science 67: 1090-1114.

Prestlokken, E. 1994. Ekspanderbehandling av kraftfør til drøvtyggere. (Expanded concentrate supplements for ruminants). Faginfo Nr. 6. NHL-Fagtjenesten, Husdyrforsøksmøtet. p. 128-133.
Rae, R.C., Ingalls, J.R. \& McKirdy, J.A. 1983. Response of dairy cows to formaldehyde-treated canola meal during early lactation. Canadian Journal of Animal Science 63: 905-915.

Robertson, J.B. \& Van Soest, P.J. 1981. The detergent system of analysis and its application to human foods. In: James, W.D.T. \& Theander, O. (eds.). The Analyses of Dietary Fibre in Foods. New York, NY, Marcell Dekker. p. 123-158.

Robinson, P.H., Khorashani, G.R. \& Kennaly, J.J. 1994. Forestomach and whole tract digestion in lactating dairy cows fed canola meal treated with variable levels of acetic acid. Journal of Dairy Science 77: 552-559.

- \& McNiven, M. 1994. Influence of flame roasting and feeding frequency of barley on performance of dairy cows. Journal of Dairy Science 77: 3631-3643.

SAS. 1987. SAS/STAT ${ }^{\mathrm{TM}}$ Guide for Personal Computers. Version 6 Edition. SAS Institute, Gary, NC. 1028 p.

Sjaunja, L.O., Baevre, L., Junkkarinen, L., Pedersen, J. \& Setälä, J. 1990. A Nordic proposal for an energy corrected milk (ECM) formula. $27^{\text {th }}$ Session International Commitee of Recording and Productivity of Milk Animal. Paris, France p. 156-157.

Small, J.C. \& Gordon, F.J. 1990. A comparison of response by lactating cows given grass silage to changes in the degradability or quantity of protein offered in the supplement. Animal Production 50: 391-398.

Somogyi, M. 1945. A new reagent for the determination of sugars. Journal of Biological Chemistry 160: 61-68.

Theodorou, M.K., Williams, B.A., Dhanoa, M.C., McAlIan, A.B. \& France, J. 1994. A simple gas production method using a pressure transducer to determine the fermentation kinetics of ruminant feeds. Animal Feed Science and Technology 48: 185-197.

Thomas, C. \& Rae, R.C. 1988. Concentrate supplementation of silage for dairy cows. In: Garnsworthy, P. (ed.). Nutrition and Lactation in the Dairy Cow. Butterworths, London. p. 327-354.

Tuori, M. 1992. Rapeseed meal as a supplementary protein for dairy cows on grass silage-based diet, with the emphasis on the Nordic AAT-PBV feed protein evaluation system. Agricultural Science in Finland 1: 367-439. -, Kaustell, K., Valaja, J., Aimonen, E., Saarisalo, E. \& Huhtanen, P. 1995. Rehutaulukot ja ruokintasuositukset. (Feed Tables and Feeding Recommendations). Helsinki, Yliopistopaino. 99 p.

Tyrrel, H.F. \& Reid, R.A. 1965. Prediction of energy value of cow's milk. Journal of Dairy Science 48: 1215-1223. Van Keulen, J. \& Young, B.A. 1977. Acid insoluble ash as a natural marker for digestibility studies. Journal of Animal Science 44: 282-287.

Van Vuuren, A. M., Huhtanen, P. \& Dulphy, J.-P. 1995. Improving the feeding and health value of ensiled forages. In: Journet, M. et al. (eds.). Recent Developments in the Nutrition of Herbivores. INRA, Paris. p. 297-307. Voigt, J. \& Piatkowski, B. 1991. Stickstoffumsatz im Verdauungstrakt von Milchkühen. 42nd Annual Meeting of EAAP, Berlin. p. 442.

Whitelaw, F.G., Milne, J.S., Ørskov, E.R. \& Smith, J.S. 1986. The nitrogen and energy metabolism of lactating cows given abomasal infusion of casein. British Journal of Nutrition 55: 537-556. 


\title{
AGRICULTURAL AND FOOD SCIENCE IN FINLAND
}

Huhtanen, P. \& Heikkilä, T. Treated barley and rapeseed meal for dairy cows

\section{SELOSTUS}

\section{Ohran ja rypsirouheen fysikaalisen käsittelyn vaikutus maidontuotantoon säilörehuun perustuvalla ruokinnalla}

\author{
Pekka Huhtanen ja Terttu Heikkilä \\ Maatalouden tutkimuskeskus
}

Tutkimuksessa selvitettiin ohran ja rypsirouheen fysikaalisen käsittelyn vaikutuksia säilörehun syöntiin ja maidon tuotantoon. Koe tehtiin cyclic change-over koejärjestelyn mukaan käyttämällä 24 ay-lehmää. Kokeessa oli neljä 21 pv:n pituista koejaksoa. Kuusi koeruokintaa järjestettiin $2 \times 3$ faktoriaalisesti ja koostuivat käsittelemättömästä (UB) ja käsitellystä ohrasta (TB), joita molempia annettiin joko ilman lisävalkuaista (kontrolli) tai joko käsittelemättömän tai fysikaalisesti suojauskäsitellyn rypsin kanssa. Säilörehua lehmät saivat vapaasti ja väkirehua $10 \mathrm{~kg} / \mathrm{pv}$ koko kokeen ajan. Rypsi korvasi $2 \mathrm{~kg} / \mathrm{pv}$ perusväkirehusta, joka ohran lisäksi sisälsi melassoitua juurikasleikettä $(200 \mathrm{~g} / \mathrm{kg})$.

Ohran suojauskäsittely vähensi merkitsevästi säi- lörehun syöntiä. Maitotuotokseen ohran käsittely ei vaikuttanut, mutta pienemmän maidon rasvapitoisuuden vuoksi energiakorjattu maitotuotos väheni. Ohran käsittely lisäsi merkitsevästi maidon valkuaispitoisuutta, mutta ei vaikuttanut valkuaistuotokseen. Rypsi lisäsi säilörehun syöntiä, maitotuotosta, maidon valkuaispitoisuutta sekä kaikkien maidon komponenttien tuotosta. Rypsin suojauskäsittely ei lisännyt tuotosta käsittelemättömään rypsiin verrattuna, vaikka ohutsuolesta imeytyvän valkuaisen laskennallinen saanti lisääntyi vähentyneen valkuaisen pötsihajoavuuden seurauksena. Tulokset osoittavat, että rehun valkuaisarvon määrittäminen pelkästään nailonpussimenetelmällä määritettyyn pötsihajoavuuteen johtaa rehun valkuaisarvon yliarviointiin. 